\title{
How impulsiveness and variety influence food intake in a sample of healthy women
}

Citation for published version (APA):

Guerrieri, R., Nederkoorn, C., \& Jansen, A. T. M. (2007). How impulsiveness and variety influence food intake in a sample of healthy women. Appetite, 48, 119-122. https://doi.org/10.1016/j.appet.2006.06.004

Document status and date:

Published: 01/01/2007

DOI:

10.1016/j.appet.2006.06.004

Document Version:

Publisher's PDF, also known as Version of record

Document license:

Taverne

Please check the document version of this publication:

- A submitted manuscript is the version of the article upon submission and before peer-review. There can be important differences between the submitted version and the official published version of record.

People interested in the research are advised to contact the author for the final version of the publication, or visit the DOI to the publisher's website.

- The final author version and the galley proof are versions of the publication after peer review.

- The final published version features the final layout of the paper including the volume, issue and page numbers.

Link to publication

\footnotetext{
General rights rights.

- You may freely distribute the URL identifying the publication in the public portal. please follow below link for the End User Agreement:

www.umlib.nl/taverne-license

Take down policy

If you believe that this document breaches copyright please contact us at:

repository@maastrichtuniversity.nl

providing details and we will investigate your claim.
}

Copyright and moral rights for the publications made accessible in the public portal are retained by the authors and/or other copyright owners and it is a condition of accessing publications that users recognise and abide by the legal requirements associated with these

- Users may download and print one copy of any publication from the public portal for the purpose of private study or research.

- You may not further distribute the material or use it for any profit-making activity or commercial gain

If the publication is distributed under the terms of Article $25 \mathrm{fa}$ of the Dutch Copyright Act, indicated by the "Taverne" license above, 


\title{
How impulsiveness and variety influence food intake in a sample of healthy women
}

\author{
Ramona Guerrieri*, Chantal Nederkoorn, Anita Jansen \\ Department of Experimental Psychology, Maastricht University, P.O. Box 616, 6200 MD Maastricht, the Netherlands
}

Received 3 May 2006; accepted 23 June 2006

\begin{abstract}
This study investigates to what extent an impulsive personality, a varied food environment and their interaction influence food intake. We also investigated whether high-impulsives would exhibit more "eating disordered" thoughts and behaviours. Forty-five lowimpulsives and forty-one high-impulsives did a bogus taste test with varied or monotonous food. As expected, high impulsives had a higher food intake compared to low impulsives. Moreover, high-impulsives reported significantly more "eating disordered" thoughts and behaviours than low-impulsives. Neither a main effect of variety nor an interaction between variety and impulsivity were found.

(C) 2006 Elsevier Ltd. All rights reserved.
\end{abstract}

Keywords: Impulsivity; Inhibitory control; Variety; Eating disorders

\section{Introduction}

Impulsivity is generally defined as responding with insufficient forethought, planning or control which results in an inaccurate or maladaptive action (Solanto et al., 2001). Impulsivity is associated with all kinds of pathologies ranging from addictions to ADHD (Nasser, Gluck \& Geliebter, 2004; Solanto et al., 2001). In the realm of eating behaviour and eating disorders impulsivity has also become a key concept. Research has shown that obese children (Nederkoorn, Braet, Van Eijs, Tanghe, \& Jansen, in press), obese women with Binge Eating Disorder (Nasser et al., 2004) and restrained eaters (Nederkoorn, Van Eijs \& Jansen, 2004) are more impulsive than controls. Moreover, impulsivity is a risk factor for eating disorder behaviour in adolescents (Wonderlich, Connolly \& Stice, 2004). Also, priming "lack of control" thoughts - with impulsivity being one of the priming words - led to an increased food intake in normal-weight women (Rotenberg et al., 2005). A logical interpretation of this research is that impulsive people are more vulnerable to the omnipresent temptation of tasty food in our obesogenic environment. Conse-

\footnotetext{
*Corresponding author. Tel.: + 3143388 4049; fax: + 31433884199 .

E-mail address: r.guerrieri@psychology.unimaas.nl (R. Guerrieri).
}

quently, they overeat. This tendency to overeat can, in turn, lead to overweight or to the development of compensatory habits that might result in eating pathology. However, the basic assumption that impulsivity in an obesogenic environment leads to increased food intake is still in its infancy and previous research is incomplete for three reasons. First, actual food intake is rarely measured. Apart from Rotenberg and colleagues, we could find only one other study. Nasser and colleagues (Nasser et al., 2004) hypothesised a positive correlation between food intake and self-report impulsivity scores, but did not find it. Second, mostly clinical groups are investigated. Again, only Rotenberg and colleagues (Rotenberg et al., 2005) used normal-weight women. If impulsivity is a cause of obesity, a relation between impulsivity and food intake should be found and replicated in normal, lean people. Third, the interaction between impulsivity and environmental factors has not been studied. The environmental factors that promote overeating are availability and palatability of food, large portion sizes and variety (Hill \& Peters, 1998; Rolls et al., 1980). Overweight children appeared more vulnerable to triggers of overeating than normal-weight children: they overate after pre-exposure to tasty food, but not without this exposure (Jansen et al., 2003). It is possible that impulsivity is the cause of this 
vulnerability in obese people and that impulsive people are less able to resist tempting food.

The aim of the current study was to investigate whether impulsivity of the participant and variety of the presented food would influence the participants' food intake. First, we expected that participants with high impulsivity scores (behavioural as well as self-report) would eat more than participants with low impulsivity scores. Second, it was hypothesized that the presentation of varied food would increase food intake compared to the presentation of monotonous food. Third, the variety of the food was thought to influence the food intake of high-impulsive participants more than that of low-impulsive participants. In other words, we expected an interaction between the factors of impulsivity and variety. Fourth, it was hypothesized that impulsivity within a non-clinical population is associated with more "eating disordered" thoughts and behaviours.

\section{Method}

Participants. Eighty-six female undergraduates were recruited (mean age: 20.23 years \pm 3.35 ; mean BMI: $21.82 \pm 3$ ). All participants were randomly assigned to the variety or the monotony group and tested individually. All participants received course credit or a monetary reward.

Measures. Impulsivity was measured both by a behavioural measure, the stop-signal task (Logan et al., 1997), and a self-report measure, the Barratt Impulsiveness Scale (BIS; Patton, Stanford, \& Barratt, 1995). In the stop-signal task impulsivity is operationalized as a decreased prepotent response inhibition (Logan et al., 1997). The stop-signal reaction time (SSRT) used as a dependent variable. The BIS measures motor impulsiveness (acting without thinking), attentional impulsiveness (not focusing on the task at hand, cognitive instability) and nonplanning impulsiveness (lack of orientation to the future) (Patton et al., 1995). Scores range from 0 to 120. "Eating disordered" thoughts and behaviours were measured by the restraint scale (RS; Herman \& Polivy, 1980) and the Eating Disorders Examination Questionnaire (EDE-Q; Fairburn \& Beglin, 1994). The RS assesses attitudes towards weight, degree and frequency of dieting, loss of control over eating and weight fluctuations. Scores range from 0 to 40 . The EDE-Q measures four sorts of dysfunctional thoughts and behaviours: restraint, eating concern, shape concern and weight concern. Scores range from 0 to 6.

Procedure. At recruitment, participants were asked to eat something small like a sandwich $2 \mathrm{~h}$ before testing and to otherwise refrain from eating or drinking (except water). At their arrival all participants stated that they had followed instructions. Hence, we can assume that differing states of hunger prior to the taste test were controlled for.

All participants started with the stop-signal task as described by Logan and colleagues (Logan et al., 1997). After this computer task both groups of participants received a bowl filled with approximately $1600 \mathrm{~g}$ of "sugar beans". These are almond-shaped chocolate candies covered in a layer of sugar. For the variety group the bowl contained 14 different colours of sugar beans. The monotony group was presented with an equal amount of plain white beans with identical taste and texture. Under the guise of a taste test participants were left alone for $15 \mathrm{~min}$ to taste the beans and to fill in a bogus taste perception questionnaire. After $15 \mathrm{~min}$ the experimenter returned and removed the sugar beans. The beans were weighed before and after the taste test to establish food intake in grams. While the experimenter was off weighing the beans the participants filled in the questionnaires (RS, BIS, EDE-Q). Lastly, participants were weighed and measured.

\section{Results}

A 2 (high vs. low impulsives) by 2 (variety vs. monotony) between-subjects ANOVA with the logarithmically transformed food intake as the dependent variable was conducted. When a median-split of the BIS score $(=66)$ was used to differentiate high-impulsives from lowimpulsives, high-impulsives ate significantly more sugar beans compared to low-impulsives, $F(1,82)=5.06$, $p=0.03$ (see Table 1). However, variety in colour did not lead to an increase in food intake $(F(1,82)=0.357$, $p=0.55)$, and the interaction effect $(F(1,82)=0.685$, $p=0.41)$ between impulsivity and variety was not significant.

When the participants were categorized as high or low impulsive, based on the stop-signal task (median SSRT $=159.44$ milliseconds), no influence of impulsivity on food intake was found $(F(1,81)=0.17, p=0.68)$, nor an interaction between impulsivity and variety $(F(1$, $81)=0.17, p=0.95)$.

Independent samples $t$-tests were conducted to find out whether high-impulsives exhibited more dysfunctional thoughts and behaviours as measured by the RS and the EDE-Q and its four subscales (see Table 1). This was the case for the total EDE score $(t(84)=2.59 ; p=0.01)$ and for three subscales of the EDE-Q: eating concern

Table 1

Means and standard errors on relevant variables for high and low impulsives

\begin{tabular}{|c|c|c|c|c|}
\hline \multirow{2}{*}{$\begin{array}{l}\text { Dependent and independent } \\
\text { Measures }\end{array}$} & \multicolumn{2}{|c|}{ Low impulsives } & \multicolumn{2}{|c|}{ High impulsives } \\
\hline & M & SEM & M & SEM \\
\hline BIS total & 59.18 & 0.80 & 74.38 & 0.83 \\
\hline Stop signal reaction time & 165.07 & 9.56 & 163.23 & 6.41 \\
\hline Food intake (in grams) & 14.76 & 1.93 & 20.86 & 2.86 \\
\hline RS & 10.02 & 0.82 & 12.18 & 1.05 \\
\hline EDE-total & 1.09 & 0.13 & 1.71 & 0.19 \\
\hline EDE-restraint & 1.00 & 0.15 & 1.45 & 0.20 \\
\hline EDE-eating concern & 0.49 & 0.08 & 0.93 & 0.17 \\
\hline EDE-shape concern & 1.47 & 0.17 & 2.34 & 0.24 \\
\hline EDE-weight concern & 1.40 & 0.18 & 2.11 & 0.25 \\
\hline
\end{tabular}


$(t(84)=2.36 ; \quad p=0.02), \quad$ shape concern $\quad(t(84)=2.96$; $p=0.00)$ and weight concern $(t(84)=2.29 ; p=0.03)$. High and low impulsives did not differ significantly on the restraint subscale of the EDE-Q $(t(84)=1.84$; $p=0.07)$ and on the $\operatorname{RS}(t(84)=1.64 ; p=0.11)$.

When the participants were categorized as high or low impulsive based on the stop-signal task, as opposed to the self-report measure, no significant differences between high and low-impulsives were found, neither on the RS, nor on the total EDE-Q score or its subscales.

\section{Discussion}

The results of this study lend added credibility to the possibility that impulsivity causes people to eat more. In time, this could lead to overweight or to compensatory habits that might result in eating pathology. Previous research has shown that obese women and children are more impulsive than normal-weight controls (Nasser et al., 2004; Nederkoorn et al., in press). The current study adds to this that impulsiveness also influences food intake in normal-weight healthy women: high-impulsive women eat more in the lab compared to low-impulsive women. Highimpulsive women ingested on average an additional $27 \mathrm{kcal}$ compared to low impulsive women. According to calculations by Levitsky (2005) an average daily increase of $5-8 \mathrm{kcal}$ is sufficient to lead to considerable weight gain in the long term. Since impulsivity leads to a fourfold increase it certainly seems a relevant factor.

The hypothesis that high-impulsives would exhibit more "eating disordered" thoughts and behaviours compared to low-impulsives, was partly confirmed. High-impulsive participants exhibited significantly more dysfunctional thoughts and behaviours as measured by the EDE-Q and three of its subscales. For the RS and the restraint subscale of the EDE-Q a trend in the same direction was noticeable. This finding again supports the hypothesis that impulsivity is a risk factor for eating disordered behaviour such as overeating. It is in accordance with previous research by Wonderlich and colleagues (Wonderlich et al., 2004) who found that behaviourally measured impulsivity predicted eating disorder behaviours such as binging and purging. Of course, this does not mean that impulsivity will necessarily lead to clinical eating problems. The scores of the highimpulsive participants stayed below the cut-off scores for Bulimia Nervosa.

The effect of impulsivity on food intake and on "eating disordered" thoughts and behaviours was only found when participants were categorized based on a self-report measure of impulsivity as opposed to a behavioural measure. Lijffijt et al. (2004) had a comparable problem: he categorized healthy participants as high or low impulsive based on a self-report measure of impulsivity. No differences in the speed of inhibiting a response were found between the groups. Lijffijt et al. (2004) suggested that the behavioural measure was not sensitive enough to detect differences in a non-clinical population. Another possibility is that the behavioural task measures another aspect of impulsivity compared to the self-report measure. In the current study, the measures did not correlate at all $(r=-0.02 ; p=0.83)$ and this lack of convergent validity between different measures of impulsivity is often reported in the literature (Wingrove \& Bond, 1997).

As far as the influence of variety on food intake is concerned, the current study could not confirm that variety in colour leads to increased food intake. Possibly, merely varying colour was not strong enough as a manipulation to affect food intake. Varying colour together with taste and/or texture might be a better option, since it has already shown to increase food intake (Rolls et al., 1980). Future research should focus on whether highly impulsive participants are more sensitive to this kind of variety in food.

In conclusion, in normal-weight, healthy women impulsivity seems to go together with a heightened food intake and with more "eating disordered" thoughts and behaviours. This is in accordance with previous research that has identified impulsivity as a risk factor for eating disorder behaviour such as bingeing and purging.

\section{References}

Fairburn, C. G., \& Beglin, S. J. (1994). Assessment of eating disorders: Interview or self-report questionnaire? International Journal of Eating Disorders, 16, 363-370.

Herman, C. P., \& Polivy, J. (1980). Restrained eating. In A. J. Stunkard (Ed.), Obesity (pp. 208-225). Philadelphia: Saunders.

Hill, J. O., \& Peters, J. C. (1998). Environmental contributions to the obesity epidemic. Science, 280, 1371-1374.

Jansen, A., Theunissen, N., Slechten, K., Nederkoorn, C., Boon, B., Mulkens, S., et al. (2003). Overweight children overeat after exposure to food cues. Eating behaviors, 4, 197-209.

Levitsky, D. A. (2005). The non-regulation of food intake in humans: Hope for reversing the epidemic of obesity. Physiology and Behavior, $86,623-632$.

Lijffijt, M., Bekker, E. M., Quik, E. H., Bakker, J., Kenemans, J. L., \& Verbaten, M. N. (2004). Differences between low and high trait impulsivity are not associated with differences in inhibitory motor control. Journal of Attention Disorders, 8, 25-32.

Logan, G. D., Schachar, R. J., \& Tannock, R. (1997). Impulsivity and inhibitory control. Psychological Science, 8, 60-64.

Nasser, J. A., Gluck, M. E., \& Geliebter, A. (2004). Impulsivity and test meal intake in obese binge eating women. Appetite, 43, 303-307.

Nederkoorn, C., Braet, C., Van Eijs, Y., Tanghe, A. \& Jansen, A. (in press). Why obese children cannot resist food: The role of impulsivity. Eating Behaviors.

Nederkoorn, C., Van Eijs, Y., \& Jansen, A. (2004). Restrained eaters act on impulse. Personality and Individual Differences, 37, 1651-1658.

Patton, J. H., Stanford, M. S., \& Barratt, E. S. (1995). Factor structure of the Barratt Impulsiveness Scale. Journal of Clinical Psychology, 51, 768-774.

Rolls, B. J., Rowe, E. A., Rolls, E. T., Kingston, B., Megson, A., \& Gunary, R. (1980). Variety in a meal enhances food intake in man. Physiology \& Behavior, 30, 185-192.

Rotenberg, K. J., Lancaster, C., Marsden, J., Pryce, S., Williams, J., \& Lattimore, P. (2005). Effects of priming thoughts about control on anxiety and food intake as moderated by dietary restraint. Appetite, 44, 235-241.

Solanto, M. V., Abikoff, H., Sonuga-Barke, E., Schachar, R., Logan, G. D., Wigal, T., et al. (2001). The ecological validity of delay aversion 
and response inhibition as measures of impulsivity in AD/HD: A supplement to the NIMH multimodal treatment study of $\mathrm{AD} / \mathrm{HD}$. Journal of Abnormal Child Psychology, 29, 215-228.

Wingrove, J., \& Bond, A. J. (1997). Impulsivity: A state as well as a trait variable. Does mood awareness explain low correlations between trait and behavioural measures of impulsivity? Personality and Individual Differences, 22, 333-339.

Wonderlich, S. A., Connolly, K. M., \& Stice, E. (2004). Impulsivity as a risk factor for eating disorder behavior. Assessment implications with adolescents. International Journal of Eating Disorders, 36, 172-182. 